\title{
THE FOSSIL GOLD PLACERS OF THE WITWATERSRAND
}

\section{A Review of their Mineralogy, Geochemistry and Genesis}

\author{
Dieter K. Hallbauer \\ Chamber of Mines of South Africa Research Organization, Johannesburg, \\ South Africa \\ Jackson M. Barton, Jr. \\ Department of Geology, Rand Afrikaans University, Johannesburg, South Africa
}

\begin{abstract}
The Witwatersrand deposits, which contain the largest known gold and uranium accumulations on earth, are located within a basin-shaped sequence of sedimentary rocks. They have a scintillating record, not only of their association with human history, but also as far as their geological past is concerned.
\end{abstract}

Situated in one of the oldest geological units on the African continent, the Kaapvaal Craton (Figure 1), the Witwatersrand deposits have, since their formation about 2800 million years (Ma) ago, witnessed the break-up of the large continent Gondwanaland, the shifting of continents and the subsequent distribution of continents as we know them today.

The more contemporary history of exploration and exploitation of the deposits began 100 years ago, and so far there is no end in sight. A detached and timeless observer would probably notice phases of quiescence followed by phases of renewed activity.

Judging from newspaper reports and scientific endeavours, a phase of activity is again sweeping the Witwatersrand. It is therefore appropriate to review the state of our knowledge and report on new results pertaining to the origin and nature of these deposits.

Headlines were made recently by the discoveries of new gold ore in what was thought to be a barren gap between the Carletonville and Klerksdorp goldfields. Although this is largely a triumph for the application of new geophysical techniques in Witwatersrand exploration, it is also a result of the utilization of all available new geological information. Most geological, mineralogical and geochemical information about the Witwatersrand deposits is usually only obtained as the gold-bearing conglomerates are being mined, but its application ranges from control of mining activity through metallurgy to exploring for extensions of the deposits.
Several generations of earth scientists have contributed to our present knowledge. Some of the first to recognize the deposits as fossil placers (heavy mineral accumulations in sediments) were Ballot (1) and de Launay (2). Throughout the years opinions swayed between a hydrothermal and sedimentary origin of the gold in the Witwatersrand Basin. The theory of an originally detrital origin of the Witwatersrand deposits is now well supported by qualitative and quantitative evidence. In this respect, significant contributions in the field of mineralogy were undoubtedly made by Liebenberg (3) and Ramdohr (4), who demonstrated that a wealth of information can be obtained by detailed and conscientious recording of microscopic textures.

As research progressed, new contributions were made by application of modern techniques. Sedimentology, geochemistry, isotope geochemistry, structural geology and geophysics were, and still are, applied by the research workers engaged in understanding the formation of the famous conglomerate or 'reef' deposits. But increasingly, efforts are being directed towards a more profitable exploitation by establishing local and regional models of gold distribution for predictive purposes. Other remnants of the original Basin are being sought and even the existence of other coeval basins cannot be ruled out. However, the high costs of mining and exploration require information of a high quality for decision making. The emphasis in scientific research has, therefore, shifted significantly during the last years from qualitative to quantitative results, and from areas of local interest to a regional understanding of the processes of reef formation. 


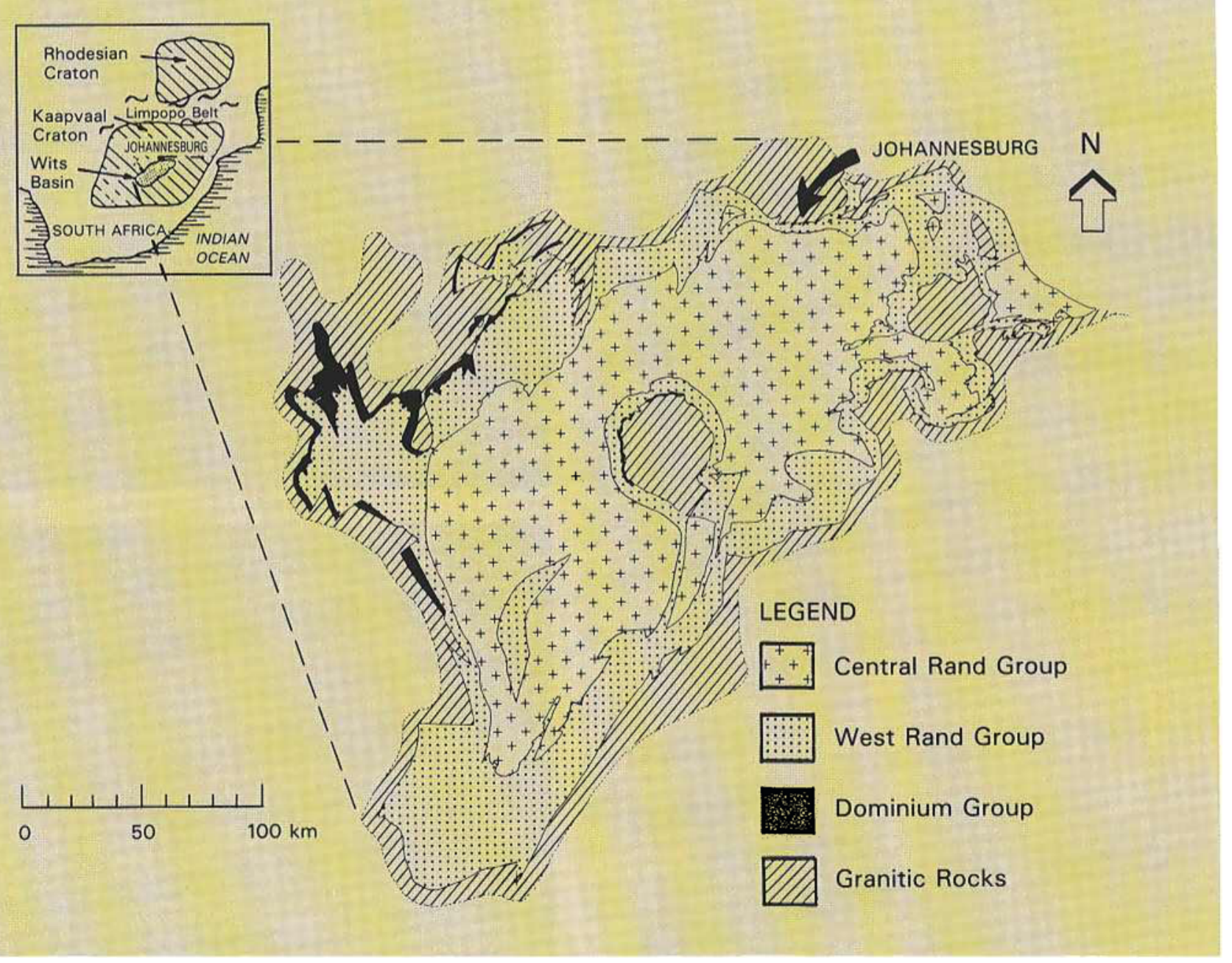

Fig. 1 Locality map showing the generalized positions of the Kaapvaal Craton, the Limpopo orogenic belt and the structure of the Witwatersrand Basin. After Pretorius (26) and Klemd et al. (18)

\section{Mineralogy and Geochemistry}

In the case of mineralogy and geochemistry, the trend from qualitative to quantitative information also has been accompanied by an application of new techniques of research. These include X-ray radiography, scanning electron microscopy, electron microprobe analyses, atomic absorption spectrophotometry and mass spectrometry for isotopic analysis, as well as computer applications for data handling and statistical analysis of the data for more meaningful interpretation.

Gold, as economically the most important constituent of the Witwatersrand conglomerates, naturally has received much attention as a carrier of geological information. Detailed sampling and sedimentological studies (5) have shown that the concentration of gold in the conglomerates can be correlated to sedimentary features that could be expected to have facilitated an enrichment of heavy minerals, in addition to gold, such as pyrite, zircon, uranium minerals and chromite. This is particularly evident from a study of $\mathrm{X}$-ray radiographs of rock slabs or core samples (Figure 2). By virtue of its high density, gold can be seen to be enriched in the sandy matrix of the conglomerate, on planes and surfaces within the sediment pile where sorting by water took place (cross beds, unconformities etc.), and within fossil algal mats. Only locally has some gold been mobilized by post-depositional processes and moved for short distances within the rocks.

The size of the gold particles is small with an average of about $120 \mu \mathrm{m}$. Nuggets, as are formed in modern placers, are absent. This absence has been attributed (6) to there having been a reducing environment during the deposition of the Witwatersrand reefs. It has also been suggested that a large proportion of the gold has retained its original detrital morphology (Figure 3) and that transport distances for the detritus have not been more than about $50 \mathrm{~km}(7)$. 


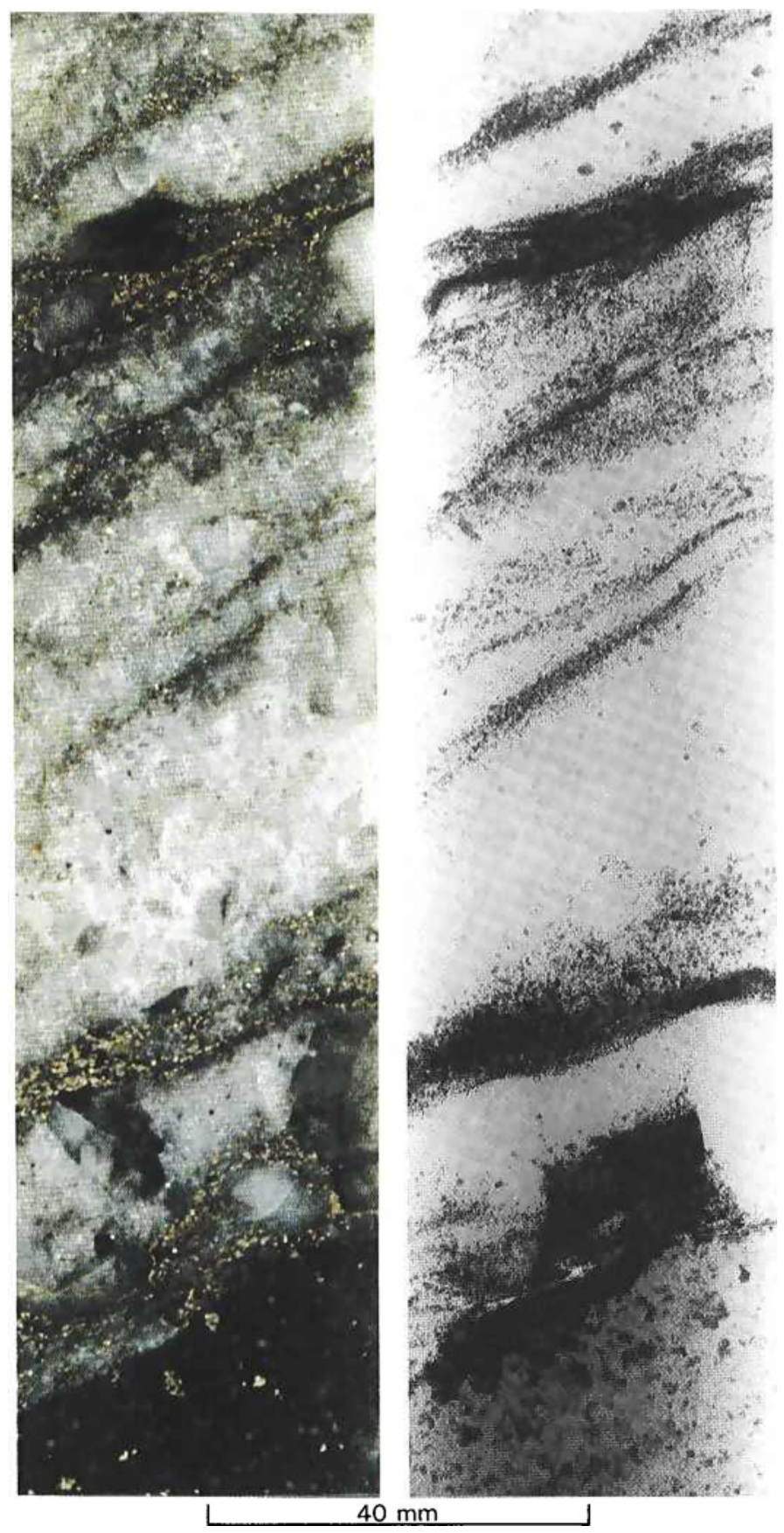

Fig. 2 Section through a bore-hole core of Ventersdorp Contact Reef showing, on the left, the surface features with quartz pebbles and quartzite (white) and the pyrite concentrations of the footwall contact and on the crossbeds, and on the right, an X-ray radiograph displaying the internal texture based on the distribution of gold particles in the sedimentary environment and also allowing an estinate of their particle size

Until recently, the evidence for this postulate was largely based on the shape and composition of gold particles, and was thus somewhat tentative. The application of isotopic analysis, however, has provided more quantitative support for this hypothesis. It was thus found (8) that de-

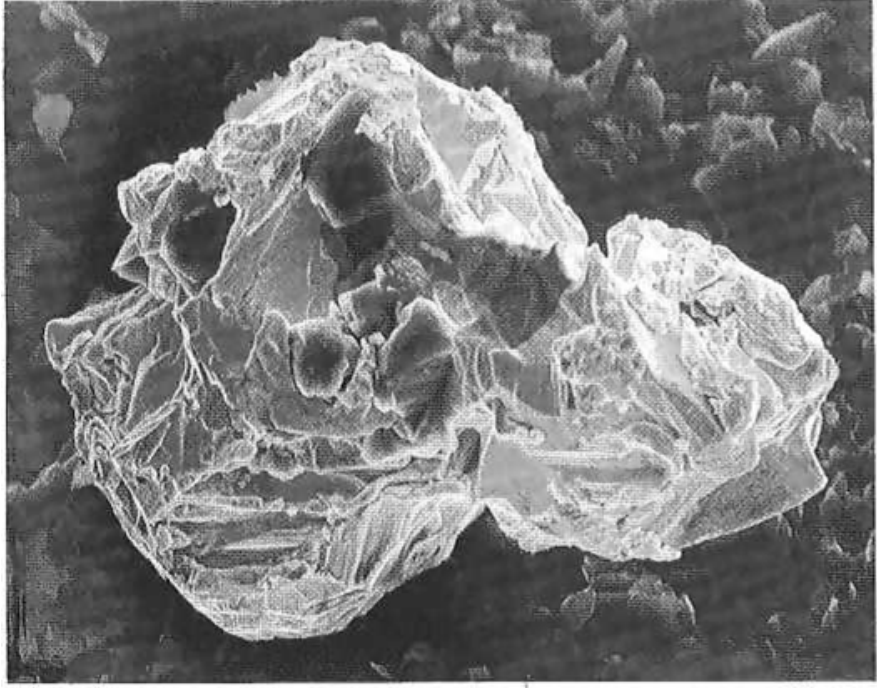

a. $20 \mu \mathrm{m} \mathrm{L}$

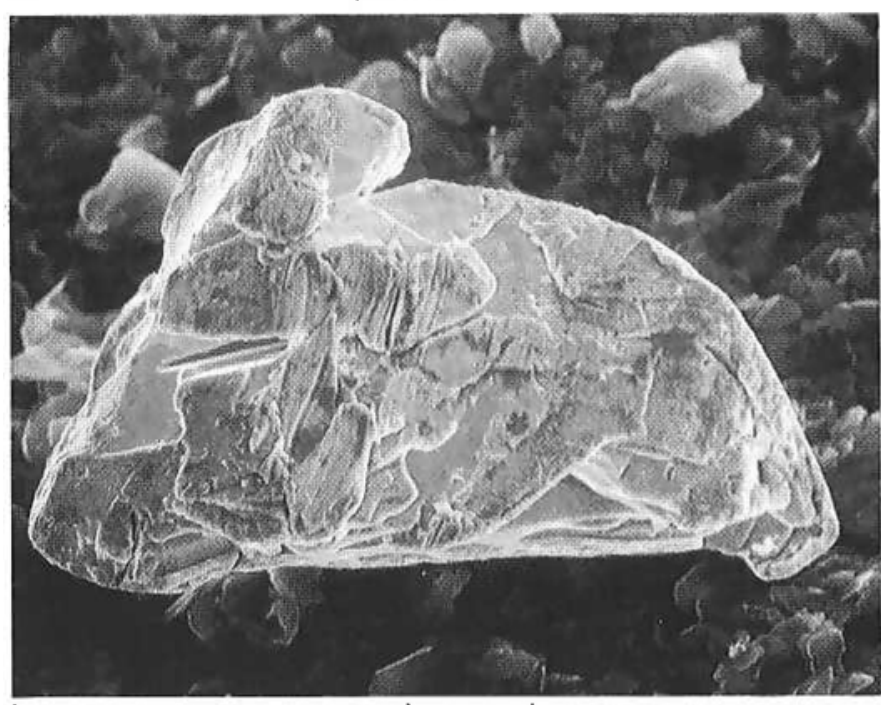

b.

$10 \mu \mathrm{mL}$

Fig. 3 Detrital gold particles after liberation from reef samples by hydrofluoric acid, showing typical mechanical deformations sustained during transport in a river environment (SEM micrograph).

Top: gold particle from the Ventersdorp Contact Reef at the Kloof Gold Mine; botton: gold particle from the Carbon Leader Reef at the Blyvooruitzicht Gold Mine. It also shows small particles of chromite which were embedded in the softer gold during transport (arrows)

trital gold, pyrite and sphalerite from the Basal Reef at the St. Helena Gold Mine in the Orange Free State have leadisotopic compositions indicating an age of about $3200 \mathrm{Ma}$. As this age is clearly older than an age of sedimentation of about $2800 \mathrm{Ma}(9)$, it probably reflects the age of the primary source deposit and is thus evidence for the detrital nature of these minerals. This also implies that other features of gold particles, such as their composition, could be used to trace the distribution of gold particles from a particular, although unknown, source or sources. 


\section{Table I}

\section{Comparison of Compositions of Gold from Witwatersrand Reefs and from Vein Deposits in the Barberton Mountain Land}

$\begin{array}{lll} & \text { Witwatersrand } & \text { Barberton } \\ \mathrm{Ag} & 1-35 \% & 5-20 \% \\ \mathrm{Hg} & 0.54-4.5 \% & <500 \mathrm{ppm} \\ \mathrm{Zn} & 0.1-0.5 \% & <100 \mathrm{ppm} \\ \mathrm{Cu} & 100-500 \mathrm{ppm} & 100-5000 \mathrm{ppm} \\ \mathrm{Co} & 100-500 \mathrm{ppm} & <10 \mathrm{ppm} \\ \mathrm{Pb} & <100 \mathrm{ppm} & <10 \mathrm{ppm} \\ \mathrm{Sb} & <100 \mathrm{ppm} & 100-1000 \mathrm{ppm} \\ \mathrm{As} & 100-500 \mathrm{ppm} & <100 \mathrm{ppm}\end{array}$

Distribution patters or geochemical facies (body of rock having the same geological or geochemical parameters over significant lateral extent) have been defined in a study of the Ventersdorp Contact Reef (VCR) in the Carletonville goldfield (10) and have, in some cases, been useful units for valuation of mine properties. This study also showed that there is no 'Witwatersrand-type gold' from a geochemical point of view, but instead groups of gold compositions. Significant differences, however, do exist between gold occurring in pre-Witwatersrand rocks of the Barberton Mountain Land and that from the Witwatersrand sediments. Some of these differences, such as the mercury and zinc contents, are shown in Table I. They serve as a strong indication that rocks of the Barberton Mountain Land-type could not have been a major source of gold in the Witwatersrand Basin.

Gold particles that fit into the range of 'Witwatersrand gold' have been found in small quantities (up to $80 \mathrm{ppb}$ ) in the altered granitic rocks along the western and northwestern margin of the Witwatersrand Basin $(11,12)$. They also occur in a similar range of grain sizes (Figure 4a) and even display the same type of intergrowths with other minerals, i.e. with cobaltite, pyrite, chalcopyrite and sphalerite. These occurrences could have been low-grade, large-volume sources for the Witwatersrand detritus (11). Although presently these mineralized granites are of no importance as mining ventures, their existence nevertheless supports the hypothesis of near-Basin sources influencing the gold distribution in Witwatersrand reefs. Their presence could also lead to a discovery of yet unknown depositories.

One of the strange yet interesting and economically important constituents of the Witwatersrand gold deposits are seams of a coal-like substance, previously called thucholite or carbon (3), which has given the Carbon Leader Reef its name. During the last decade, considerable research has been directed towards unravelling its nature. Almost all available techniques of analysis have been employed at various stages of investigation and it is now generally accepted that this carbonaceous matter is the remains of algal and/or bacterial mats that flourished in the shallow waters of the depositional environments of some of the Witwatersrand placers $(13,14)$. Large amounts of gold and uranium were trapped by the micro-organisms, resulting in the rich deposits of the Carbon Leader, Vaal and other reefs of today. Some of the gold caught in the biogenic mats was apparently redistributed around filamentous organisms, thus preserving their morphology (Figure 4b).

The most conspicuous heavy mineral, however, and the component that characterizes the well-mineralized reefs is pyrite, with its various genetic and morphological species. Most important, from a geological point of view, is the detrital, allogenic (of external origin) pyrite. Grains of this variety are usually abraded crystals or crystal aggregates which attained their shape during transport and during abrasion in an aqueous environment (Figure 4c). The source of this type of pyrite can be either external to the Basin or pyrite derived from erosion of pre-existing reefs.

Interestingly, detrital pyrites preserve the characteristics of their sources in the form of fluid and mineral inclusions (Figure 4d). These inclusions are typical of hydrothermal processes and can provide geochemical fingerprints of the source deposits outside the Basin. This assumption was tested on a regional scale in the VCR of the Carletonville goldfields, where three major types of detrital pyrite can be discerned (10). Their distribution was delineated and could also be correlated to geochemical facies based on gold particle fineness (Figure 5). This example demonstrates not only the influence of sources on distribution patterns, but also the potential of using pyrite trace-element compositions as a tool for the identification of reefs and facies within a reef.

However, trace element analysis is not a simple tool to use, and only recent advances in analytical technology have allowed its application to large numbers of samples and with the necessary precision. With the techniques presently available, only $2 \mathrm{mg}$ of sample are needed to determine 24 trace elements by atomic absorption spectrophotometry. This means that single pyrite grains can be analysed and, by testing the composition of at least 10 grains per locality, variations or consistent compositions along a direction of sediment transport can be detected. It is similarly possible to reveal a mixing of sediments from different sources (10).

Apart from the detrital, allogenic pyrite, there are a number of other varieties, such as the authigenic pyrite (formed in situ after deposition) and a group of synsedimentary pyrites (6) (formed during depositional processes). The latter group is of importance as indicators of conditions in the depositional environment during the formation 

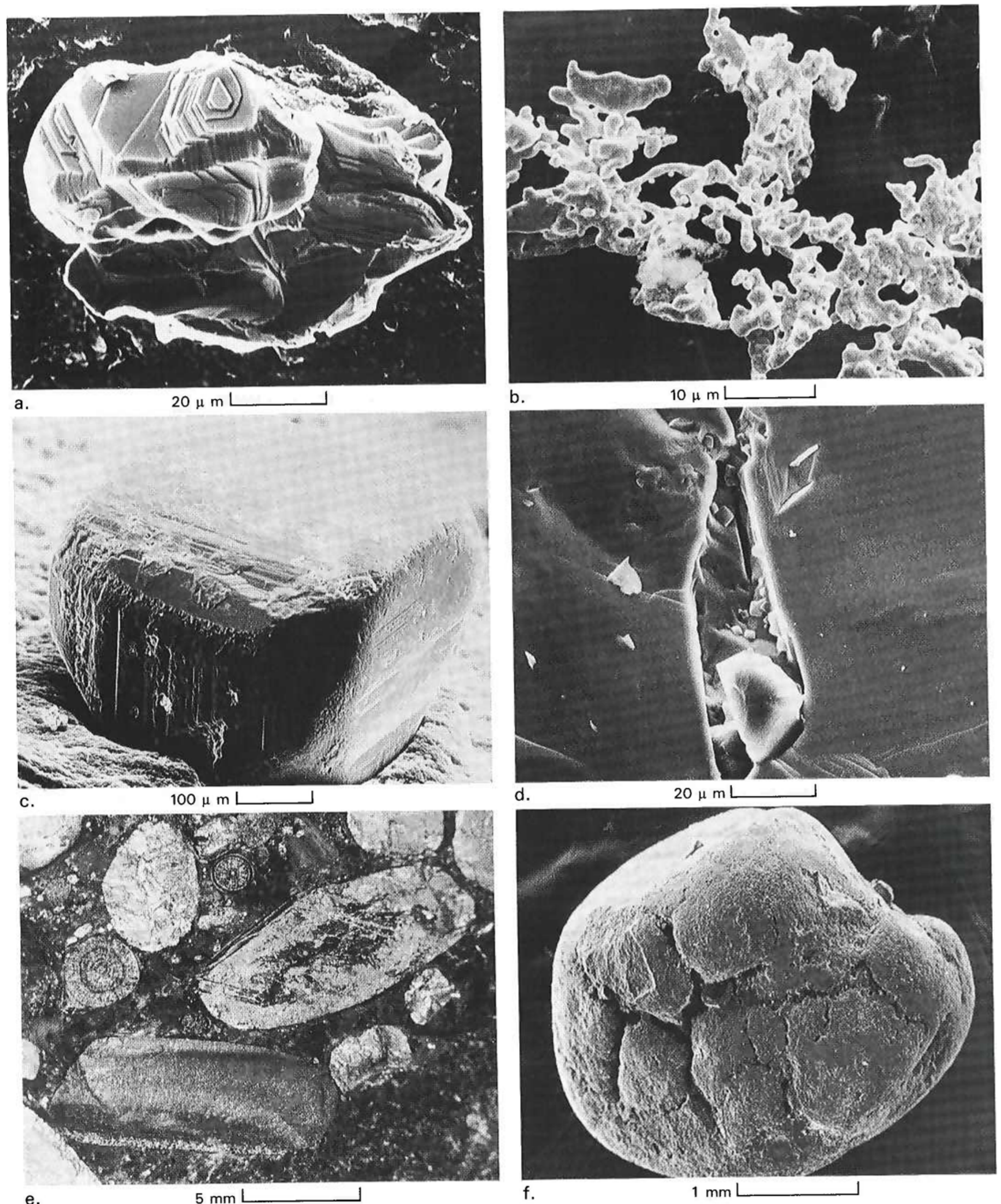
Figure 4 (a-f)

a Particle of crystalline gold extracted from a pre-Witwatersrand granitic rock exposed to the north of Johannesburg (SEM micrograph)

b Filamentous gold recovered from carbonaceous matter ('carbon') after low temperature ashing. A resemblance to algal and/or bacterial morphology is evident (SEM micrograph)

c Detrital pyrite, slightly rounded during transport in water (SEM micrograph)

d An opened fluid void in a sample of detrital pyrite indicating its hydrothermal origin by the presence of sodium chloride (arrows) accompanied by a small quartz 'daughter' crystal (SEM micrograph)

e Grains of oolitic pyrite (arrows) and other types of synsedimentary pyrite in a section of VCR from the Driefontein gold mine

f Example of a 'mudball' pyrite demonstrating typical desiccation cracks in a fine-grained pyrite aggregate (SEM micrograph)

Fig. 5 The distribution of geochemical facies on the Ventersdorp Contact Reef horizon as obtained from gold and pyrite geochemistry of the Witwatersrand reefs, and also, from an economic point of view, because of their considerable gold content.

The synsedimentary pyrites are thought to have been formed from fine-grained pyrite mud, and could thus have scavenged all other fine-grained material including gold. Some of these pyrites, characterized by a concentric and/or radial structure, were probably formed by winnowing and accretionary action in relatively quiet waters. These socalled oolitic pyrites (Figure 4e) occur in grain sizes of up to several millimetres, and are a characteristic feature of parts of the VCR, Elsburg and other reefs.

A more abundant variety of synsedimentary pyrites has been termed mudball pyrite. It consists of a very finegrained matrix and often shows evidence of subaerial drying in the form of polygonal mudcracks (Figure 4f). Its presence indicates that sedimentation was not continuous but stretched over long periods of time. Synsedimentary pyrite has also been suggested as evidence for a low oxygen content of the atmosphere in Witwatersrand times (before

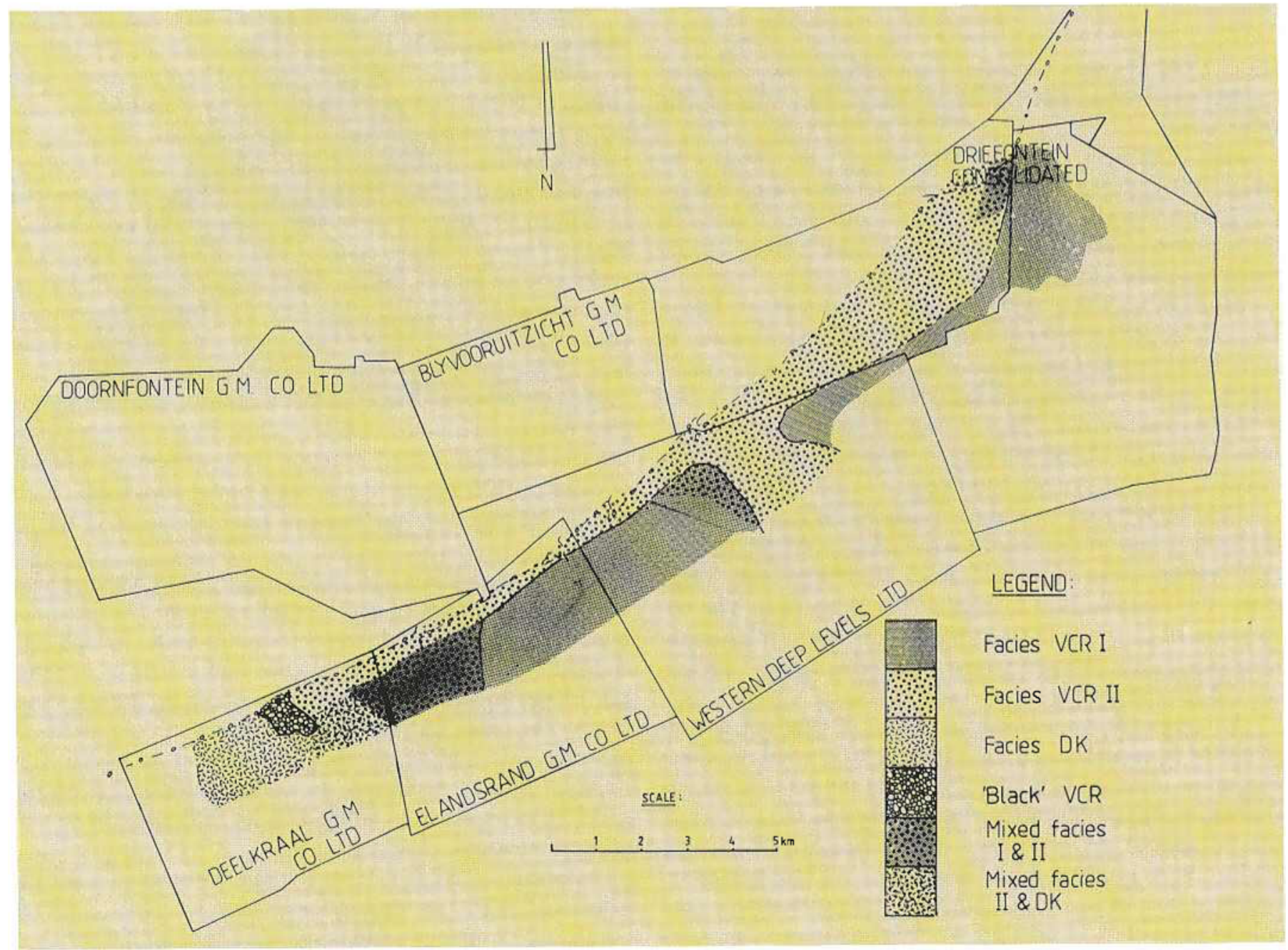




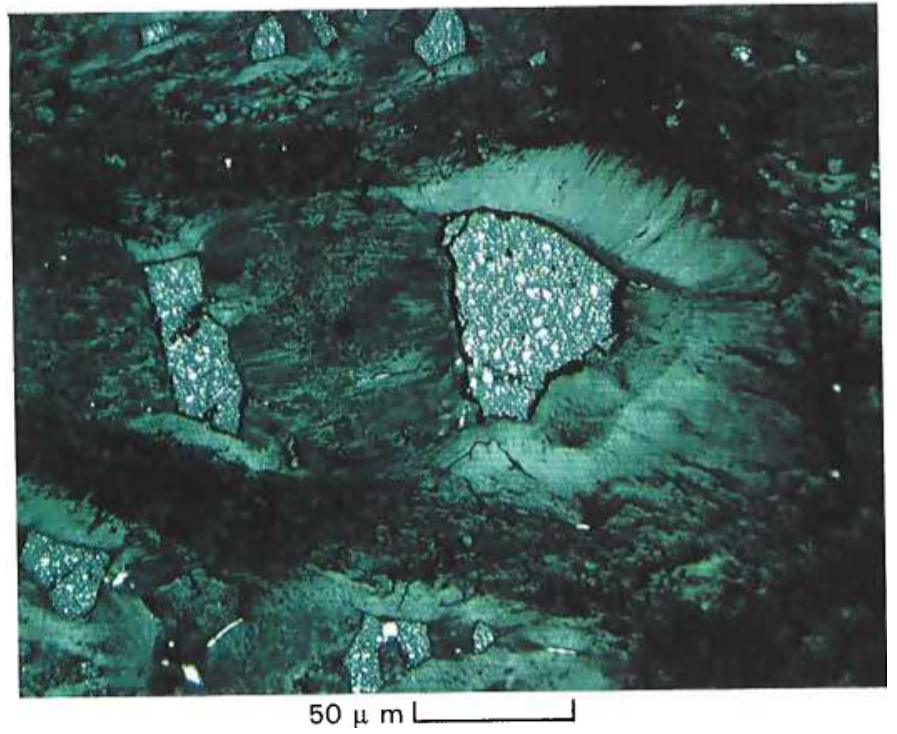

Fig. 6 Uraninite grains with inclusions of radiogenic galena (white) surrounded and 'digested' by carbonaceous matter that exhibits a filamentous texture. Polished specimen photoggraphed in polarized light (by courtesy of $R$. Frankenhauser)

about $2800 \mathrm{Ma}$ ago) since fine-grained pyrite would not be stable under present oxidizing conditions (numerous references).

Less frequent is the occurrence of framboidal (raspberry-textured) pyrite. By analogy with modern deposits, this morphology is assumed to have been formed by the action of reducing bacteria in a relatively quiet lagunal environment or perhaps under marine conditions.

Much more stable under sediment transport conditions but less abundant than pyrite is chromite. Its content in reefs is seldom high enough to be conspicuous, although it can be useful as an additional parameter to define facies within a reef horizon. The Witwatersrand chromite typically has a high chromium content (15) and often a significant zinc content of up to 5 per cent.

New importance was given to chromite recently when chromite grains of the same composition as the Witwatersrand variety were separated from altered granitic rocks along the northwestern margin of the Basin (12). The occurrence of chromite in this environment suggests a genetic link between the Witwatersrand gold, other detrital materials and altered granite.

Although the economic importance of uranium has diminished in recent years, the presence of detrital uraninite and other uranium-bearing minerals in the reefs is, nevertheless, an important factor closely linked to the genesis of the Witwatersrand deposits. It demonstrates that granitic sources were involved in the Witwatersrand sedimentation. In the context of this paper, however, not much more detail will be presented on uranium in reefs and the reader is re- ferred to an excellent paper by Smits (16). Yet the story of uranium would not be complete without mentioning its concentration in carbonaceous matter. The break-up or 'digestion' of detrital uraninite which occurs in a similar fashion to gold, and the incorporation of both into the carbonaceous matter, indicates active redistribution by biogenic processes (Figure 6).

True to the hypothesis that the Witwatersrand detritus originated from erosion of granitic and, to a lesser extent, from greenstone rocks, i.e. from altered basic igneous rocks that characterize large areas of the Archaean Kaapvaal Craton of southern Africa, the reef deposits also contain enrichments of the heavy minerals formed in such rocks. Zircon, rutile and its variety leucoxene, together with tourmaline, cobaltite, arsenopyrite, sphalerite and a few others are found in varying quantities in most reefs. Sphalerite from the Basal Reef has been found to be a geochemically important, detrital constituent when recently its lead-isotopic age was determined at $3200 \mathrm{Ma}$, the same as the lead-isotopic age of gold and pyrite from the same locality (8).

Any description of Witwatersrand ores has not ended without a reference to the pebbles that make up the bulk of the conglomerates. They have received comparatively little attention in the past and are often only classified by sedimentologists into durables and non-durables, according to their behaviour during transportation. From this classification also stems the division of conglomerates as oligomictic or polymictic, according to the proportion of non-durable pebbles, such as shale clasts, to durable ones. Polymictic rocks as seen by a petrologist could thus be classified as an oligomictic assemblage although they might encompass such diverse clast types as black, grey, white and opalescent blue-vein quartz, chert, banded chert and banded iron formation (BIF). It is thus apparent that much information on clast distribution patterns is lost when such a simple bipartite classification is used. Data on the geochemical diversity of quartz pebbles showed that reefs and groups within reefs can be identified on the basis of trace elements in quartz pebbles (17).

Similarly, clay minerals until recently have received little attention as carriers of geologic information. This group of minerals can be divided largely into muscovite, pyrophyllite and chlorite. They occur within the reef matrix or as separate shale layers. Some could also occur in altered shear zones. The value of the clay minerals lies in their ability to preserve information on the environment in which they were formed or deposited, as well as information on the rocks or minerals from which they were derived by weathering and tectonic processes.

Information on the depositional environment is usually associated with the contents of trace elements, such as boron, rubidium and vanadium, which are highly enriched 
in marine environments and depleted in river water (27). All three elements are enriched in muscovite-bearing shale layers associated with the Carbon Leader Reef, and plot in the field of marine shales (Figure 7). It can be assumed, therefore, that the Carbon Leader Reef, for a period during its formation, had been in a marine environment long enough for these elements to transfer from the sea water into the lattice of the clay minerals.

The significance of such an observation lies in the influence an environment can exert on the distribution patterns of gold within a placer deposit. Unidirectional patterns could result from a fluvial environment, whereas omnidirectional patterns could be expected to form during marine influence. However, more detailed work is needed to provide more definitive answers in this context.

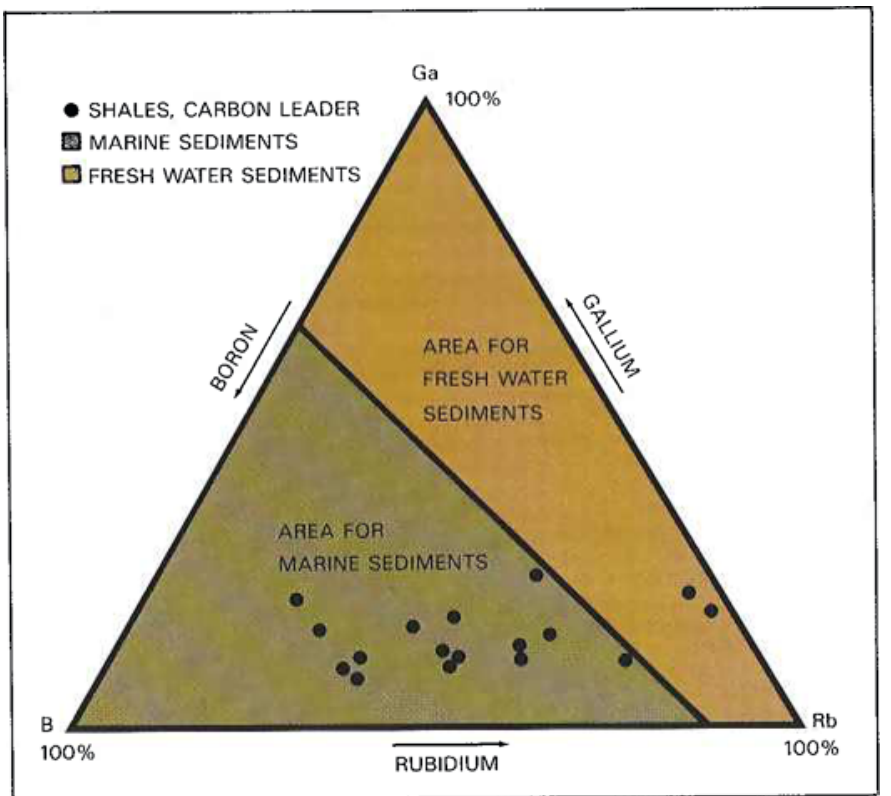

Fig. 7 Relative proportions of the trace elements boron, galliun and rubidium in freshwater and marine sediments (27), with the trace element contents of shales from the Carbon Leader horizon superimposed

\section{Faulting}

The present spatial distribution of gold-bearing reefs in the Witwatersrand Basin is, to a large extent, controlled by faulting. Several periods of faulting have affected these rocks (Table II), creating displacements both parallel and oblique to bedding planes. This faulting removed reef from certain areas and repeated it in others. Many shale horizons near and in Witwatersrand reefs have served as planes of dislocation during deformation. Furthermore, some reefs composed of two or more bands of conglomerate
Table II

\section{Structural Evolution of the Witwaters- rand Basin Based on Available Information from the Potchefstroom- Klerksdorp Area}

\section{$\pm 2050 \mathrm{Ma}$ Emplacement of Bushveld Complex \\ $\pm 2050 \mathrm{Ma}$<smiles>[CH]1[CH]CCC1</smiles> \\ $\pm 2150 \mathrm{Ma}$ \\ $\pm 2200 \mathrm{Ma}$ \\ \begin{tabular}{l|l} 
Thrust Faulting & $\begin{array}{l}\text { Local Alteration Related } \\
\text { to the Bushveld Complex } \\
\text { Emplacement }\end{array}$
\end{tabular} \\ Wrench Faulting \\ Normal Faulting \\ Vredefort Structure? \\ Deposition of the Transvaal Sequence \\ Unconformity}

$\pm 2250$

$\pm 2500 \mathrm{Ma}$

$\pm 2700 \mathrm{Ma}$

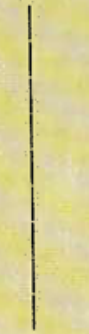

$\pm 2800 \mathrm{Ma}$

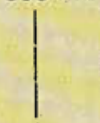

$\pm 3050 \mathrm{Ma}$
Various Periods Faulting and Thrusting

Deposition of the Ventersdorp Supergroup (and Limpopo Orogeny)

Normal Faulting | Kameeldoorns Sedimentation

Thrust Faulting | Turffontein-Klipriviersberg Sedimentation

Deposition of the Witwatersrand Supergroup

Emplacement of the Ventersdorp and Schweizer-Reneke Granite

Deposition of the Dominion Group

Emplacement of the Johannesburg and Vredefort Granodiorite 
Ages derived from this muscovite tell us when movement occurred on the faults. Each set of faults has its own characteristic geometry and strain motion resulting from a specific set of stresses at a specific time. By determining the age of motion on a specific fault and comparing it to known geological stress systems, the direction of motion could often be predicted and with it the movement of reef horizons.

There is evidence for many different paleo-environments in rocks of the Witwatersrand Basin. Subaerial environments are indicated by the presence of mudballs, mudcracks and sand dunes. Fluvial environments are indicated by the presence of channels. Wave-zone environments are characterized by the presence of extensive well-

Fig. 8 Sketches depicting the formation of reef duplications by shear movement in the plane of the reef (bedding plane faulting).

a Onset of shearing by horizontal contraction of sedinents

b Reef duplication after prolonged movement along the shear zone sorted features, such as those found in the Vaal Reef and marine environments; they are indicated by the thick accumulations of shale present in the Basin.

While it is possible, given sufficient time, that all these environments could exist in one place, it is also possible, considering the amount of faulting indicated in the rocks, that rocks from different environments might be juxtaposed by faulting. The Basin could have been telescoped or shortened considerably. It is of critical importance, therefore, for planes of dislocation to be identified and motion along them documented in time and space. Only then can the original shape of the Basin be reconstructed. This will allow people to reconstruct properly the original distribution of the rock units present, and to predict and understand the distribution of gold. A more meaningful stratigraphy for the Basin can then be defined and sedimentological studies can be confidently undertaken. In an effort to gain better insight into the 3-dimensional distribution of fault struc-

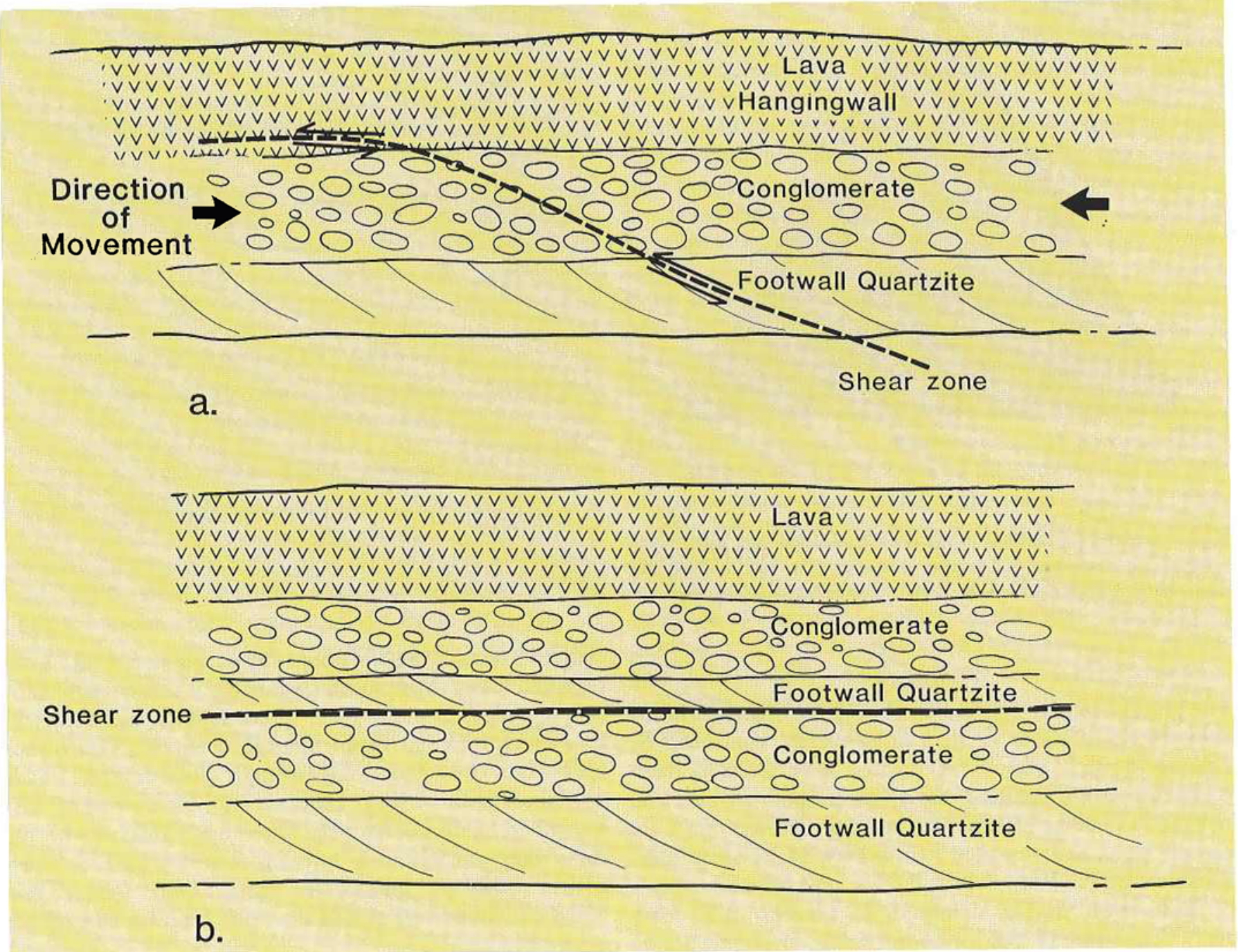


tures and rock units in Witwatersrand Basin, a vast expenditure of time and money is presently being made, utilizing the seismic geophysical technique of vibrosis.

\section{Metamorphism of the Witwatersrand Basin}

When the sediments filling the Witwatersrand Basin were deposited, they contained up to 40 per cent water by volume trapped in pore space between grains. During this diagenesis (the turning of sediments into rocks), much of this water was expelled and it moved out of the Basin. Furthermore, many rocks within the Witwatersrand Basin contain minerals which indicate that they were subjected to temperatures typically up to $250^{\circ} \mathrm{C}$, but occasionally up to $400^{\circ} \mathrm{C}$ or higher.

Fig. 9 Underground exposure of Ventersdorp Contact Reef, duplicated by shear movement. $S_{1}-S_{4}$ indicate shear zones
The interaction of water with rocks at elevated temperatures in the Witwatersrand Basin had a profound influence on the distribution of certain elements. These fluids moved, at least in part, along shear zones where they reacted with ground rock to produce, among other minerals, muscovite, pyrrhotite and other sulphides. Many of these shear zones are parallel to bedding and occur in reef zones (Figure 9) where they are often mistaken as being merely shale horizons.

Recently, Klemd et al. (18) discovered connate brines in fluid inclusions in some altered granitic rocks along the northwestern margin of the Basin. These brines, whose presence characterize the so-called Mississippi Valley-type ore deposits, contain hydrocarbons and are capable of transporting base metals, uranium, thorium and rare earth elements, and possibly gold. They were probably derived from the Witwatersrand Basin. Where, if at all, the metals being carried by these connate brines were deposited, de-

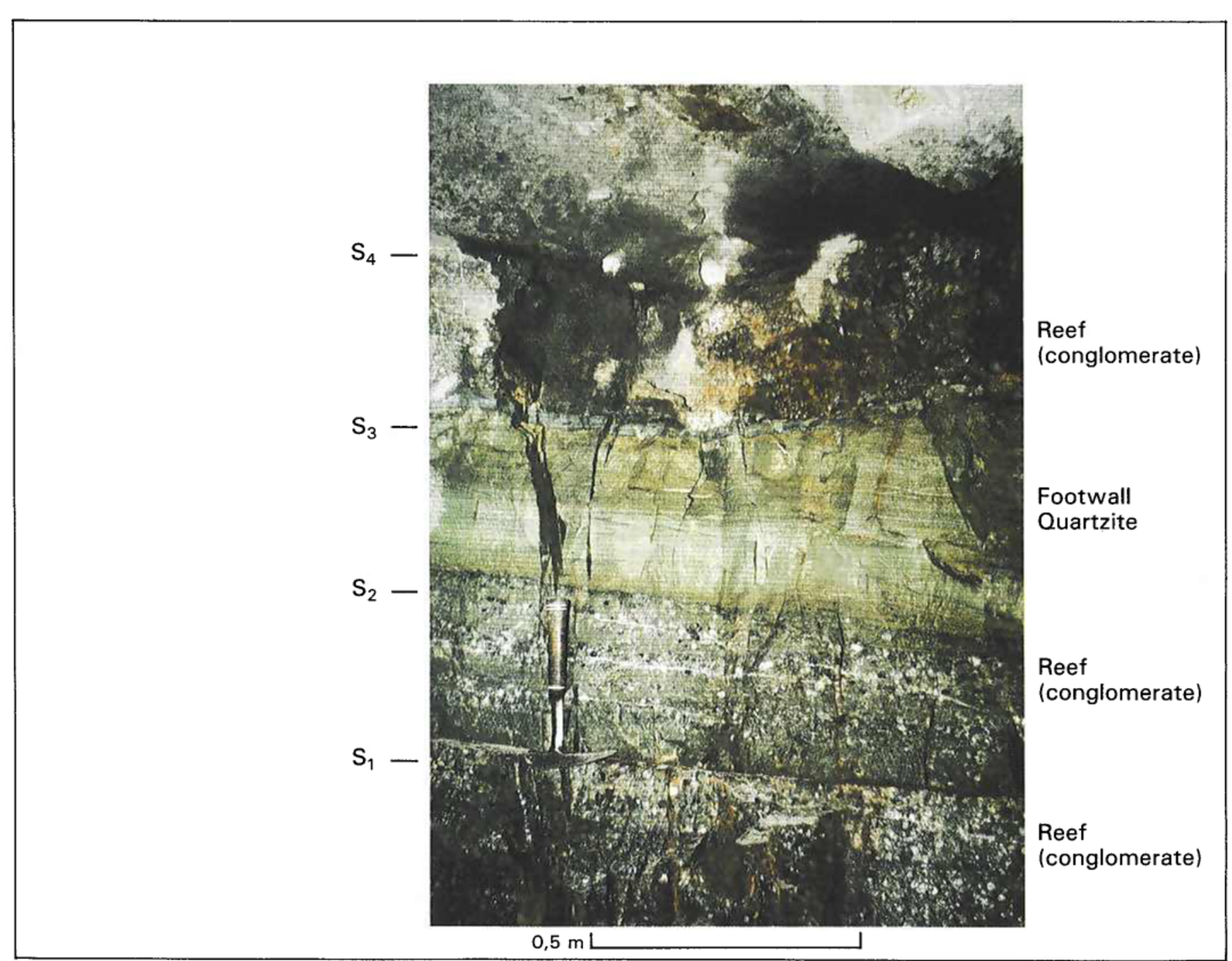


pended on their encountering the correct wall-rock compositions. But connate brines can travel distances in the order of hundreds of kilometres before they deposit some of their metals. The recognition of connate brines as being associated with the evolution of the Witwatersrand Basin may lead to the implementation of new exploration philosophies.

\section{Time Constraints}

Other important factors in the formation of a placer deposit are: the time needed for its formation; the time available for the processes to form the placer; and, with regard to available sources and other geological processes that formed the Witwatersrand Basin, the time span within which it was actually formed.

Some diggers' tales relate that smaller gold placers have been found to be rejuvenated after the relatively short time span of about 100 years. This would suggest that the primary source or sources had been in close proximity, fairly concentrated and available for weathering processes. Giant placers like some of the Witwatersrand reefs, however, contain far more gold than even the largest California placers, and no highly concentrated gold deposits are yet known from the immediate vicinity. The time scale and concentration processes should have been, therefore, of a higher magnitude.

By assuming low-grade, large-volume sources of mineralized granitic rocks, and weathering processes of a similar magnitude as those operative today, a minimum time span for the formation of large placers can be estimated. The results of such a calculation are shown in Table III. They indicate that a minimum of 250000 years of high-rate weathering is necessary to produce the amount of detritus which, after concentration, would form a deposit like the Carbon Leader Reef.

Although this period is extremely short when seen on the geologic time scale, it still does not include the time needed to activate other geological processes necessary for placer formation. This is not inconsistent with observations on Witwatersrand placers which show that, in the majority, the reefs as we know them today are complex and multistage formations.

The age of deposition of the sediments of the Witwatersrand Basin is at present only loosely defined between the ages of approximately $3050 \mathrm{Ma}$ for the granodioritic rocks of the basement, exposed in the Johannesburg Dome (19), on which the sediments were deposited, and $2700 \mathrm{Ma}$ of the unconformably overlying lavas and sediments of the Ventersdorp Supergroup (20). Rocks of the underlying Dominion Group, situated between the basement and the Witwatersrand Supergroup, were probably deposited somewhere between about $3100 \mathrm{Ma}(21)$ and $2800 \mathrm{Ma}$ ago (22).

\section{Table III}

\section{Estimation of Time Necessary to Produce a 'Witwatersrand Reef'}

\begin{abstract}
Rock mass available from a hypothetical source area of $50 \times 50 \mathrm{~km}$, at a weathering yield of $300 \mathrm{t} / \mathrm{km}^{2} /$ year (desert-type

weathering) and a assumed average gold content of $0.1 \mathrm{~g} / \mathrm{t}$
\end{abstract}

Approximate rock mass contained in $20 \mathrm{~cm}$ of Reef over $1 \mathrm{~km}^{2}$

$0.5 \times 10^{6} \mathrm{t}$

Approximate mass of the 'West Wits' Carbon Leader area $(15 \times 25 \mathrm{~km})$

$1.9 \times 10^{8} \mathrm{t}$

Debris needed to produce a reef by sorting at a concentration factor of 1000 and a final gold content of $100 \mathrm{~g} / \mathrm{t}$. (Present day annual sediment discharge by rivers world wide $-2 \mathrm{x}$ $10^{10} t$ )

$1.9 \times 10^{11} t$

Minimum time needed to produce an area of about $15 \times 25 \mathrm{~km}$ of reef at $20 \mathrm{~cm}$ average thickness and an average gold content of $100 \mathrm{~g} / \mathrm{t}$ by weathering and sorting

250000

years
Recently, Brink (23) demonstrated that sedimentation of the Central Rand Group (formerly Upper Witwatersrand) strata, including that of the gold-bearing reefs, was controlled by thrust faulting from the west. This thrusting also affected deposition of the $2700 \mathrm{Ma}$ - old Ventersdorp sequence. Assuming that thrusting operates only over relatively short periods of time, up to $100 \mathrm{Ma}$, deposition of Central Rand Group rocks probably occurred in the interval between $2800 \mathrm{Ma}$ and $2700 \mathrm{Ma}$ ago.

The formation and evolution of the depository into which the rocks of the Witwatersrand Supergroup were deposited was complicated and must be viewed, not in isolation, but in terms of regional tectonism of the Kaapvaal Craton (20). What is commonly termed the Witwatersrand Basin today is probably a series of remnants of one or more basins. Basin edges are rarely if ever exposed and the continual discovery of outliers of rocks, particularly of the lower Witwatersrand sediments, argues that the depository when these rocks were being laid down was considerably more extensive than today, perhaps even extending to the Pietersburg and Barberton greenstone belts (9). The basin in which the rocks of the Central Rand Group sediments were being deposited was probably smaller in extent, and sediments in it were, in part, formed by erosion of West 
Rand Group rocks. Details about the basin in which the rocks of the Dominion Group were deposited have not been published.

The coarseness of much of the sediments making up the Witwatersrand Supergroup, particularly the sandstones and reef conglomerates, implies that these sediments were derived from erosion of reasonably nearby mountains. Where the exposed remains of these mountains are today, remains moot. It has been suggested that they were part of the mountains formed during the Limpopo Orogeny (Table II) about $2700 \mathrm{Ma}$ ago $(24,25)$. To be correct, this possibility requires that the formation of the Witwatersrand Basin and the Limpopo Orogeny occurred within a few tens of millions of years around $2700 \mathrm{Ma}$ ago. However, if the Witwatersrand Basin was formed significantly prior to $2700 \mathrm{Ma}$ ago, it may be related to tectonism associated with the implacement of the $3050 \mathrm{Ma}$ granodioritic rocks presently exposed in the Johannesburg Dome, the Vredefort Dome and the Lochiel batholith of the Barberton granite-greenstone terrain (9).

Alternatively, the sediments in the Witwatersrand Basin may have been derived from a terrain in which a series of 2800 Ma granitic rocks are exposed, extending from Schweizer-Reneke to Giyani in the Sutherland greenstone belt (9). Lead-isotopic evidence suggests that a major period of gold mineralization took place in what is now the northern and eastern portions of the Kaapvaal Craton about $3200 \mathrm{Ma}$ ago, and that some detrital components in the Witwatersrand reefs were derived from such rocks, presumably when they were involved in any of these periods of mountain building.

\section{Outlook}

Gold mining today is not only a highly complex operation but also extremely capital intensive. Expectations and predictions of the grade to be mined at great depths are therefore vital to minimize the risk. Also, with a shift of mining operations from shallow deposits to stoping more than $3 \mathrm{~km}$ below surface, the emphasis of predictions moves from relatively small blocks of ground to a more regional perception of value distributions. In this paper, we have given a brief statement of the present state of our knowledge on the Witwatersrand deposits, especially their mineralogy, geochemistry and their structural place in the large entity of the Kaapvaal Craton. The geological picture which has emerged has numerous implications, not only in regard to further study of the Witwatersrand Basin, but also to future exploration and exploitation of the Basin.

\section{Acknowledgement}

The work described in this paper forms part of the research programme of the Chamber of Mines of South Africa.

\section{References}

1 J. Ballot, The Banket Formation: Its Probable Origin and Present Position, Mendelssohn \& Scott, Johannesburg, 1888

2 L. de Launay, Les mines d'or du Transvaal, Baudry, Paris, 1896

3 W.R. Liebenberg, Trans. Geol. Soc. S. Afr., 1955, 57, 101-254

4 P. Ramdohr, Trans. Geol. Soc. S. Afr., 1958, 61 Annex, 50

5 W.E.L. Minter, in Fluvial Sedimentology, A.D. Miall (cd.), Canad. Soc. Petr. Geol., 1978

6 D.K. Hallbauer, in Mineral Deposits of Southern Africa, C.R. Anhaeuser and S. Maske (eds.), Geol. Soc. S. Afr., Johannesburg, 1986, 1, 731-752

7 D.K. Hallbauer and T. Utter, Mineralium Deposita, 1977, 12, 293-306

8 L. Giusti, D.K. Hallbauer, H.L. Allsopp, I.B.Evans and H.J. Welke, Geocongress '86, Extended Abstracts, Geol. Soc. S. Afr., 1986, 123-127

9 J.M. Barton Jr., C. Roering, E.S. Barton, D.D. Van Reenen and C.A. Smit, Geocongress '86, Extended Abstracts, Geol. Soc. S. Afr., 1986, 15-18

10 D.K. Hallbauer and B.G. Els, 'Gold 100', Proc. Int. Conf. Gold, SAIMM, Johannesburg, 1986, 1 ('Gold Mining Technology'), 45-62

11 D.K. Hallbauer, Proc. 12th CMMI Congress, H.W. Glen (ed.), Johannesburg, 1982, S. Afr. Inst. Min. Metall, 1982, 957-964

12 D.K. Hallbauer, K. von Gehlen, E.J.D. Kable and D. Bühmann, Geocongress '86, Extended Abstracts, Geol. Soc. S. Afr., 1986, 139144

13 D.K. Hallbauer and K.T. van Warmelo, Precamb. Res., 1974, 1 , 199-212

14 D.K. Hallbauer, Miner. Sci. Eng., 1975, 7, 111-131

15 H.V. Eales and I.M. Reynolds, Spec. Public. Geol. Soc. S. Afr., 1981, 7, ICAM 81, 5-20

16 G. Smits, Precamb. Res., 1984, 25, 37-59

17 D.K. Hallbauer and E.J.D. Kable, in Ore Genesis - The State of the Art, G. Amstutz et al. (eds.), Springer Verlag, Heidelberg, 1982, 742-752

18 R. Klemd, D.K. Hallbauer and J.M. Barton Jr., Econ. Geol., (in submission)

19 E.S. Barton, J.M. Barton Jr., M.J. Callow, H.L. Allsopp, I.B. Evans and H.J. Welke, Geocongress '86, Extended Abstracts, Geol. Soc. S. Afr., 1986, 93-97

20 R.A. Armstrong, W. Compston, E.A. Retief and H.J. Welke, Geocongress '86, Extended Abstracts, Geol. Soc. S. Afr., 1986, 89-92

21 L.O. Nicolaysen, A.J. Burger and W.R. Liebenberg, Geochim. Cosmochim. Acta, 1962, 26, 15-23

22 C.B. van Niekerk and A.J. Burger, Trans. Geol. Soc. S. Afr., 1969, 72, 37-45

23 M.C. Brink, Rand Afrikaans University, Johannesburg, 1986, (unpubl. thesis)

24 L. Reinecke, Trans. Geol. Soc. S. Afr., 1930, 33, 111-133

25 K. Burke, W.F.S. Kidd and T. Kusky, Tectonics, 1986, 5, 439-456

26 D.A. Pretorius, in Mineral Deposits of Southern Africa, C.R. Anhaeuser and S. Maske (eds.), Johannesburg, Geol. Soc. S. Afr., 1, 489-403

27 E.T. Degens, E.G. Williams and W.L. Keith, Bull. Amer. Ass. Petrol. Geol., 1957, 41, 2427-2455 